\title{
The Effect of WhatsApp Messenger As Mobile Learning Integrated with Group Investigation Method of Learning Achievement
}

\author{
Hendrik Pratama, Sulistyaning Kartikawati \\ Universitas PGRI Madiun \\ pratama@unipma.ac.id
}

\begin{abstract}
The purpose of this research was determined the effect of application WhatsApp Messenger in the Group Investigation (GI) method on learning achievement. The methods used experimental research with control group pretestpostest design. The sampling procedure used the purposive sampling technique that consists of 17 students as a control group and 17 students as an experimental group. The sample in this research is students in Electrical Engineering Education Study Program. The experimental group used the GI method that integrated with WhatsApp Messenger. The control group used lecture method without social media integration. The collecting data used observation, documentation, interview, questionnaire, and test. The researcher used a t-test for compared the control group and the experimental group's learning outcomes at an alpha level of 0,05 . The results showed differences between the experiment group and the control group. The study result of the experimental higher than the control groups. This learning was designed with start, grouping, planning, presenting, organizing, investigating, evaluating, ending's stage. Integration of WhatsApp with group investigation method could cause the positive communication between student and lecturer. Discussion in this learning was well done, the student's knowledge could appear in a group and the information could spread evenly and quickly.
\end{abstract}

Keywords: WhatsApp Messenger, Mobile Learning, Group Investigation Method, Learning Achievement

\section{Preliminary}

The use of social media has become a lifestyle for the people of Indonesia. The research was realized as the utilization of technology to improve the quality of education. Based on the survey of Indonesian Internet Service Provider Association (APJII) states that Indonesia is a country that is predominantly using social media [2]. The percentage of social media activity Indonesia reached $79.72 \%$, the highest in Asia, beating South Korea (49\%), Japan (30\%), the Philippines (78\%), Malaysia (72\%), and China (67\%). The negative impact of the use of social media must be aware of learners. Referring to research Johnson, Social media has a negative impact such as addiction to gadgets make learners rarely read books, lack of concentration learners, even destroy spelling and grammar [8].

To overcome the negative impact, WhatsApp Messenger integrated M-Learning be the right solution. Based on Lillian research, the role of $\mathrm{M}$-Learning can create a 
conducive academic atmosphere because students can learn anywhere and anytime [9]. Between learners and educators have good emotional closeness, more open in conducting feedback on an issue, and cultivate a variety of new ideas. Social media like WhatsApp Messenger is a favorite for students. The results of the questionnaire to 25 learners showed that $24(96 \%)$ using the WhatsApp Messenger. Media can send messages quickly, attach a video, image, audio, location, create a group, it is easy to send files to a file in the form of numerous extensions such as Microsoft Word, PowerPoint, portable document format and a lighter software without the aid of supporting applications. WhatsApp Messenger is a mobile learning technology that can help students to learn social, easy to construct knowledge by sharing with other group members through short messages, and ease of online interactions quickly between learners and teachers [1].

Learning conditions in Electrical Engineering Study Program PGRI UNIVERSITY MADIUN requires the concept of learning active, innovative, creative, effective, and fun. Basic Electronics material characteristics require the mastery of the theory and application. Interviews showed that the learning method is dominated by lecture, too focused on theory without applicative example, and less attractive. This is reinforced by the willingness of the low reading for learners who prefer to play smartphone than reading a textbook. The value of learning outcomes in Elementary Electronics courses is also still low with an average of 66.26. The test results of 21 learners there is one student with less grades, 17 students enough grades, and 3 students with good grades.

Laboratoratorium tool limitations resulting experimental activity is not running optimally. One teacher effort that has been applied is to use video as a virtual laboratory experiment. In line with the research, Hendrik use of video containing experimental activities makes learning more interesting delivery [7]. In this study, experimental video integrated with Whatsapp Messenger that accompanied the Student Worksheet (LKS).

Learning outcomes are influenced by the selection of appropriate learning method by the material. Appropriate learning methods are used to address the above problems is the method of Group Investigation (GI). Sumarmi GI method according to a learning method that involves small groups, students use cooperative inquiry (planning and discussion groups) then presented the findings in class [10]. This learning model requires students to have good skills in communication and group process skills. Application of the method begins by defining the problem, explore a variety of issues, gather relevant data, develop and test hypotheses.

The purpose of this research is to determine differences in the effect of the application of methods Group Investigation (GI) with WhatsApp Messenger as mobile learning to the learning outcomes of students.

\section{Research Methods}

This research was conducted at the Electrical Engineering Education Program PGRI Madiun University, street Setia Budi Madiun number 85, 63118. The population in this study is the students half of two (2) in Electrical Engineering Education Study Program. 
Samples taken consisted of 17 students to the experimental class and 17 student to the control class. The sampling procedure in this study using purposive sampling technique.

Stages of research refer to Gravemeijer \& Cobb consisting of preparing for the experiment (preparatory research, literature review, and analysis of needs), the design of experiment (the implementation of the experimental design and data collection), a retrospective analysis (analysis of data get from the previous stage) [6 ]. In this study, the approach used is an experimental research design using the Control Group pre test and post test. In the control class, the students are given a pre test. After it was treated using conventional learning. Then the learning process ends with a post test. In the experimental group, the learning process was given treatment by the method of learning Group Investigation (GI) using WhatsApp Messenger as M-learning.

Aspects of knowledge of learners tested by applying a pretest and post test form of multiple choice questions. Improved learning outcomes before and after the learning gain factor are calculated by the formula (N-Gain). The average value of achievement (N-Gain) compared to know the difference and its effectiveness. The next step, the data pre test, and post test learners tested normality and homogeneity as a prerequisite test analysis. The results of the test are used as a basic prerequisite further testing using the t-test on the cognitive learning. T-test was used to compare differences in learning methods are applied to the experimental group and the control group. The hypothesis is no difference in the effect of applying the method of Group Investigation (GI) with WhatsApp Messenger as mobile learning on learning outcomes.

\section{Results and Discussion}

\subsection{The results of M-learning Instructional Design with Whatsapp Messenger}

\section{Integrated Methods Group Investigation (GI)}

M_Learning instructional design stages with integrated Whatsapp Messenger with GI method consists of six main stages, namely grouping, planning, Investigating, organizing, and presenting.

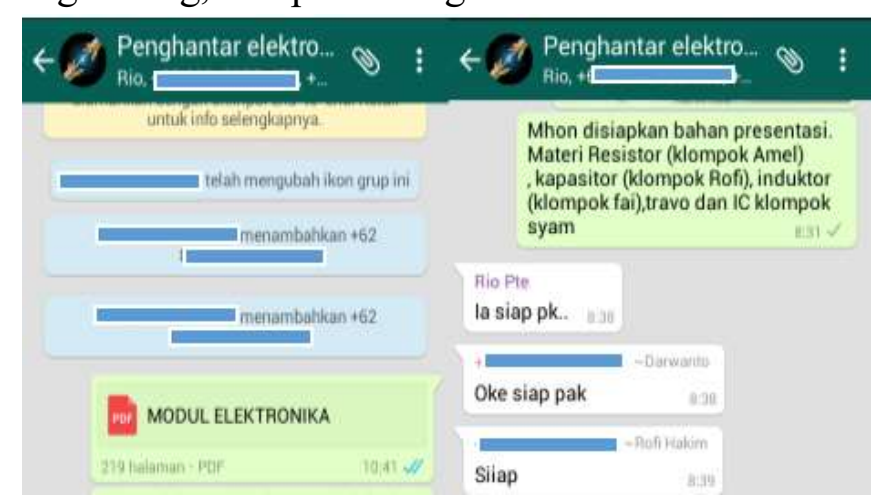
Figure 1. The Print Screen Learning Process Stage served as facilitators. The result of Grouping and Planing
Stages are starting from (1) formation of group activities on Whatsapp. Each group consists of 5 people with subtopics that had been prepared. At this stage, each group having one admin as chairman in charge to coordinate its members. Educators as well an admin who the interaction during the learning process can be seen in Figure 1. grouping, starting with the 


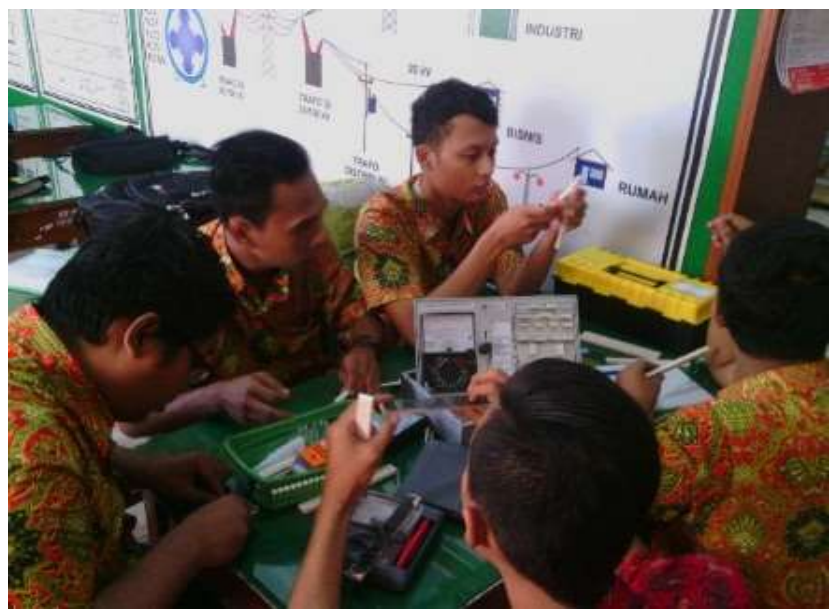

(2) Planning, the event was started discussions off the line and on line by arranging the initial hypothesis of the issues to be studied, followed by educators transmit module learners learning as the basis to solve the problem. Each group was facilitated modules contain materials and worksheets to help the investigation stage. (3) Investigating, each group conducted an investigation and the

Figure 2. Print Screen Stage Learning Processinvestigation of the initial problems Investigating and Organizing that are tailored to LKS guide you in collecting data. Before analyzed, the group sends the results of the data collection. (4) Organizing, each group analyzes the data and discuss the issues at LKS answer. Data analysis results sent to educators through WA for an evaluation. At this stage the educator can provide guidance on the results of the data analysis.

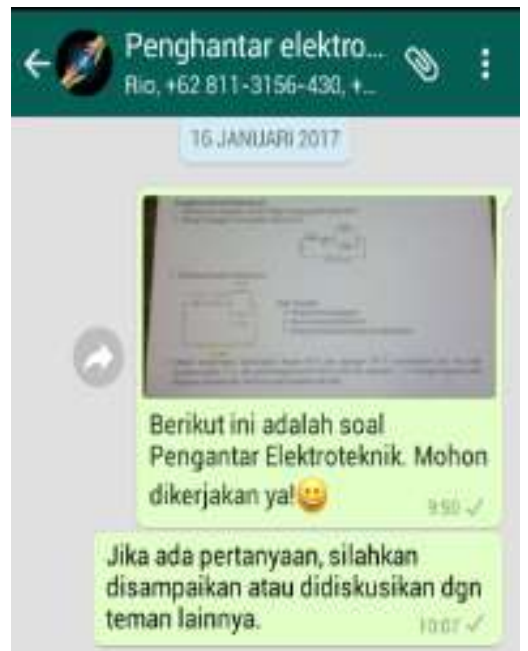

(5) Presenting, the group presented the results in the classroom. The conclusion of the presentation in the group share in WA so that all learners can learn the back. (6) Evaluating each learner concludes the discussion and presentation and continued with the evaluation of each. The value of each learner will be added to the group. Best group will get a prize of educators as appreciation. The result of the interaction during the learning process can be seen in Figure 3.

Figure 3. Print Screen Presenting Stage Learning Process and Evaluating 


\subsection{Data Description}

Table 1. Description of Cognitive Learning Outcomes Data

\begin{tabular}{llcccccc}
\hline & & \multicolumn{2}{c}{ Group Statistics } & & & \\
& & $N$ & mean & Std. deviation & Std. error Mean & Max & Min \\
\hline \multirow{2}{*}{ test2 } & Control group & 17 & 79.00 & $4: 36$ & $1: 06$ & 90 & 72 \\
& Experiment group & 17 & 84.41 & $6: 41$ & $1: 55$ & 95 & 72 \\
\hline
\end{tabular}

Table 1, shows the average cognitive learning outcomes in each sample of 17 learners. In control, class showed the average value of 79.00, a maximum score of 90 , and a minimum score of 72 . In the experimental class the mean value of 84.41 , a maximum score of 95 , and a minimum score of 72 .

\subsection{Prerequisites Test Analysis}

Table 2. Cognitive Learning Normality Test Results

\begin{tabular}{llcccccc}
\hline & & \multicolumn{4}{c}{ Tests of normality } & \multicolumn{3}{c}{ Shapiro-Wilk } \\
& Class & Statistics & $\mathrm{df}$ & $\mathrm{Sig}$. & statistics & $\mathrm{df}$ & Sig. \\
\hline cognitive & class Experiment & .125 & 32 & $.200 *$ & .963 & 17 & .683 \\
& classroom Control & .179 & 32 & .150 & .930 & 17 & .221 \\
\hline
\end{tabular}

a. Significance Lilliefors Correction

*. This is a lower bound of the true significance.

Based on Table 2, known normality test results on the cognitive achievement experimental class of 0.200 and 0.150 control class is greater than 0.0 . Then it can be taken a decision that all data on the cognitive learning normal distribution.

Table 3. Test Homogeneity Cognitive Learning Outcomes

\section{Test of homogeneity of variance}

\begin{tabular}{llcccc} 
& Levene Statistic & DF1 & DF2 & Sig. \\
\hline cognitive & Based on Mean & 2918 & 1 & 32 & .097 \\
& Based on Median & 2,683 & 1 & 32 & .111 \\
& Based on median and with adjusted df & 2,683 & 1 & 31087 & .112 \\
& Based on the trimmed mean & 2,935 & 1 & 32 & .096 \\
\hline
\end{tabular}

Based on Table 3, Test Levene's test of homogeneity of cognitive learning achievement gained significance for the experimental class of 0.097 which is greater than 0.05 , it can be concluded that the students' cognitive learning achievement data homogeneous. 


\subsection{Hypothesis Testing}

Table 4. Hypothesis Testing Cognitive Learning Outcomes

\begin{tabular}{|c|c|c|c|c|c|c|c|c|c|c|}
\hline \multicolumn{11}{|c|}{ Independent Samples Test } \\
\hline & & \multicolumn{4}{|c|}{$\begin{array}{l}\text { Levene's Test } \\
\text { for Equality of } \\
\text { Variances }\end{array}$} & \multicolumn{5}{|c|}{ t-test for Equality of Means } \\
\hline & & \multirow[b]{2}{*}{ F } & \multirow[b]{2}{*}{ Sig. } & \multirow[b]{2}{*}{$\mathrm{t}$} & \multirow[b]{2}{*}{$d f$} & \multirow{2}{*}{$\begin{array}{l}\text { Sig. (2- } \\
\text { tailed) }\end{array}$} & \multirow{2}{*}{$\begin{array}{l}\text { Mean } \\
\text { Differenc } \\
e\end{array}$} & \multirow{2}{*}{$\begin{array}{l}\text { Std. Error } \\
\text { Difference }\end{array}$} & \multicolumn{2}{|c|}{$\begin{array}{l}95 \% \text { Confidence } \\
\text { Interval of the } \\
\text { Difference }\end{array}$} \\
\hline & & & & & & & & & Lower & Upper \\
\hline \multirow[t]{2}{*}{ Kognitif } & $\begin{array}{l}\text { Equal } \\
\text { variances } \\
\text { assumed }\end{array}$ & $\begin{array}{r}2.91 \\
8\end{array}$ & .097 & 2.880 & 32 & .007 & 5.412 & 1.879 & 1.584 & 9.240 \\
\hline & $\begin{array}{l}\text { Equal } \\
\text { variances } \\
\text { not } \\
\text { assumed }\end{array}$ & & & 2.880 & 28.200 & .008 & 5.412 & 1.879 & 1.563 & 9.260 \\
\hline
\end{tabular}

Based on Table 4, a comparison test between the two classes is conducted by independent test samples give a value of 0.007 is less than 0.05 , which means the results are not the same. This means that there are differences in cognitive learning outcomes between experimental class control class.

\subsection{Discussion}

The results of this study indicate that the application of the method of Group Investigation (GI) with WhatsApp Messenger as mobile learning has a positive impact in improving learning outcomes. Referring to the analysis of the needs that the learning outcomes are low, then the appropriate GI method is applied to improve the ability to think analytically, critically, creatively, and productively so as to obtain maximum learning outcomes. According to research Doymus and Simsek, GI is suitable for learning science lessons which aims to engage students in scientific investigations and encourage students to contribute to the learning in the classroom [5]. The concept of cooperation in groups and carry out investigations as part of the stage GI method encourages students can obtain an invention.

Learning activities in this study discuss the basic electronics components that include material resistors, capacitors, inductors, diodes, transistors, transformers, and IC. Referring to the GI method, the learning process begins by analyzing the characteristics of each subject, conducting an investigation, and presenting. For example resistor material. Participants not only learn all sorts of resistors, color codes, and circuits. However, in the analytic stage, the group is required to explain the relation of resistance (R), voltage (V), and electric current (I) or known as Ohm's law. Learners are given a video about resistance analogy as the friction of hydraulic pipe and also friction in the mechanical system. Resistance or friction directly against the current, flow of water, 
movement, and energy are dissipated so that the impact of the emergence of heat. The power dissipated by resistance can be explained by the equation:

$$
P=V I=(R I) I=I^{2} R=V \frac{V}{R}=\frac{V^{2}}{R}
$$

The electric charge requires power as it passes through a resistance, then $\mathrm{V}$ in equation (1) represents a decrease in voltage in the direction of the current. Then the value of $\mathrm{V}$ is a voltage rise in the opposite direction of the current. Representation of the conventional diagram of resistance, current direction, and voltage polarity as Fig. 6. Current flows from terminal a to $b$. The plus sign $(+)$ and minus (-) represent a potential reduction from left to right (from the plus sign to the minus sign).

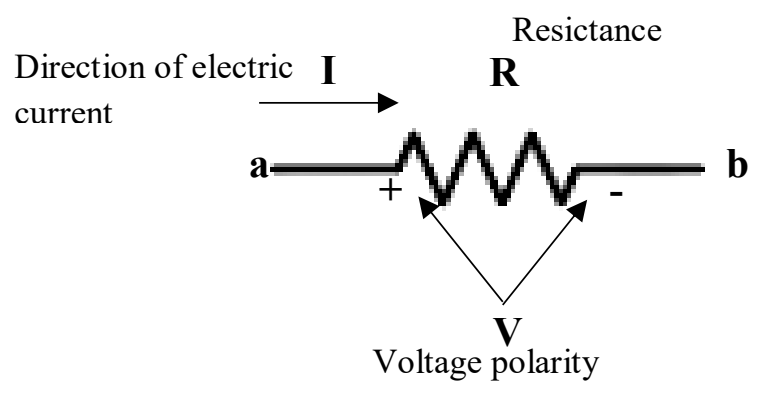

Figure 5. Schematic Representation of Resistance

At the inquiry stage, students do practicum activities to prove the theory about the resistor. Students assemble practice tools to assist in the investigation process. The results of the laboratory did not match the theory. For example, the written resistor value $50 \Omega$ obtained from the color bracelet. But the test results stated the value $48 \Omega$. If the resistor is the maximum allowable power dissipation of 2 watts so that the component is not damaged, then according to equation (1) the current flowing is limited to $0.2 \mathrm{~A}$. The difference of the theoretical results with the practice can be explained that the resistance is affected by maximum power capacity, tolerance and influence temperature. Educators provide an example through WA video to provide an explanation. For example, the carbon resistor of its resistance value will decrease as the temperature gets bigger. The rising film resistance of the silicon film increases as the temperature increases.

Whatsapp as the application of mobile learning provides a stimulating learning innovation active learners learn. Limitations of laboratory instruments solved by providing a video lab with LKS sent through WhatsApp from each group. Learners are required to perform an analysis of the video and link with learning theory. Based on these activities, seen liveliness of each group, woke communication and learning outcomes have increased. By research Amry that the application WhatsApp social networking as an effective mobile learning is applied in combination with the learning process [1]. Social networking helps students actively to communicate with fellow learners and educators easily build knowledge indefinitely. 
Differences in cognitive learning outcomes based on independent samples test between experimental class and control class looks very significant. It is evident that the experimental class learners achieve an average value of 84.41. This result is better than the control group which showed the average value of 79.00. This suggests that cognitive learning outcomes of students using WhatsApp Messenger Group Investigation integrated learning method is better than the control class using conventional methods. In line with Barhoumi research, characteristics of learning methods by integrating WhatsApp Messenger as mobile learning that combines the concept of learning face and remotely readily accepted by learners [3]. Interaction among learners with educators to become more flexible. The presence of educators as an online instructor in the group WhatsApp has added value in the learning process. Based on this surplus value, its use can be utilized to integrate the learning process. Educators able to supervise easily on learners, interact, monitor progress, motivate, provide alternative solutions to the problems faced by learners. Ability learners uneven can be facilitated by the group through WhatsApp Messenger monitored by educators. Monitor progress, motivate, provide alternative solutions to the problems faced by learners. Ability learners uneven can be facilitated by the group through WhatsApp Messenger monitored by educators.

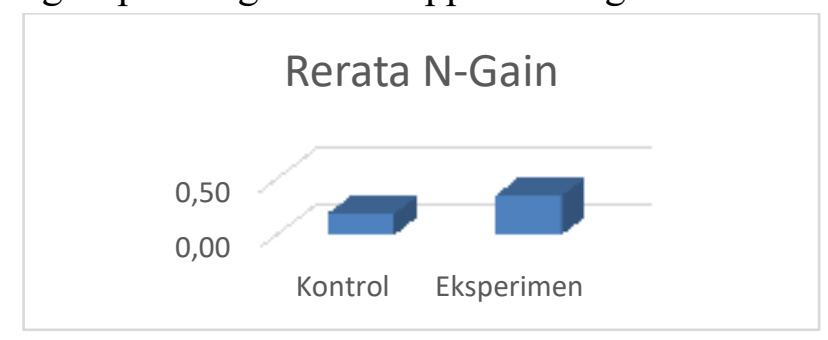

Figure 5. Graph Mean Improved Learning Outcomes

Gain test learning outcomes based on Graph 1 shows that in the control group NGain score showed the value of 0.18 which showed an increase learning outcomes in the low category. While the experimental group $\mathrm{N}$-Gain score indicates a value of 0.34 which showed an increase learning outcomes in the medium category. This means that the learning process in the classroom experiments showed a significant increase. Each of the learning process in the experimental class at any time can be observed. If there is a problem, educators as a direct facilitator can overcome. In contrast to the observation process control class is limited to school hours. At this stage prove that social media is not to be feared by educators, not for mere entertainment by learners. But it can be integrated to support learning.

\section{Conclusion}

The results showed that the use Whatsapp Messenger as an integrated mobile learning effective group investigation method to be applied in the learning process in to improve the learning outcomes of students compared to face to face learning methods usual. Social media like WhatsApp Messenger as a form of progress in science and technology capable of providing motivation for learners after integrated learning. The combination 
of social media by the method of learning Group Investigation attended the new shades for students and educators learn from each other. The design study was conducted on the start, grouping, planning, presenting, organizing, Investigating, Evaluating, ending.

Excess learning methods are applied that learning interaction among learners with educators are good, communication is easily done anywhere and anytime, enabling educators to support the concept of distance learning, discussion forums easily formed between groups of learners, it is easy to build knowledge, and easily share information rapidly.Overall, students are interested and motivated in following the learning by using WhatsApp combined with other methods investigation.

\section{Suggestion}

Long-term processes can be developed based assessment system of evaluation by WhatsApp. Assessment is done online with the rules established to train educators independence of learners. The problem can be adjusted with the ability to think of each learner. Need to develop an integrated learning model that other social media to motivate the students to learn so that the development of social media be a positive thing, not to be feared, and could be used as a means of improving learning outcomes.

\section{References}

[1] Amry, A. 2014. The Impact of Whatsapp Mobile Social Learning on the Achievement and Attitudes of Female Students Compared with Face to Face Learning in the Classroom. European Scientific Journal, 10 (22), 116-136.

[2] APJII. 2015. Indonesia Internet Users. Laporan Asosiasi Penyelenggara Jasa Internet Indonesia. Diakses pada 1 April 2015, dari http://www.apjii.or.id/v2/read/page/halaman-data/9/statistik.html.

[3] Barhoumi, C. 2015. The Effectiveness of WhatsApp Mobile Learning Activities Guided by Activity Theory on Students' Knowledge Management. Contemporary Educational Technology Journal, 6 (3), 221-238.

[4] Dewi, Rizki Puspita, et al. 2012. "Penerapan Model Group Investigation Terhadap Hasil Belajar Materi Bahan Kimia di SMP." Unnes Journal of Biology Education (1):3.

[5] Doymus K \& Simsek U. 2009. Effects of Two Cooperative Learning Strategies on Teaching and Learning Topics of Thermochemistry. The World Applied Sciences Journal 7 (1): 33-42.

[6] Gravemeijer, Koeno, and Paul Cobb. 2006. "Design Research From A Learning Design Perspective". Educational design research: 17-51.

[7] Hendrik P., Nunus W. 2016. Pengaruh Penggunaan Macromedia Sebagai Media Pembelajaran Pada Standar Kompetensi Instalasi Video Game Di SMK Gamaliel 1 Madiun. JUPITER (Jurnal Pendidikan Teknik Elektro), 1 (1), 3540.

[8] Johnson, Y., dan George D. 2014. The Impact of Whatsapp Messenger Usage on Students Performance in Tertiary Institutions in Ghana. Journal of Education and Practice, 5 (6), 157-164.

[9] Lillian, B. 2012. Scaffolding Teachers Integrate Social Media Into a ProblemBased LearningApproach. The Electronic Journal of e-Learning, 10 (1), 13-22. 
[10] Sumarmi. 2012. Model-Model Pembelajaran Geografi. Malang: Aditya Media.

[11] Susilo, A. (2014). Exploring Facebook and Whatsapp as Supporting Social Network Applicationsfor English Learning In Higher Education. 